\title{
GENERAL ARTICLES
}

Anna M. de Jong*

anna.dejong@maastrichtuniversity.nl

orcid.org/0000-0003-4851-8573

Faculty of Law

Maastricht University

Maastricht $6211 \mathrm{LH}$, the Netherlands

\section{The Cultural Goods Import Regime of Regulation (EU) 2019/880: Four Potential Pitfalls}

\begin{abstract}
This article argues that Regulation (EU) 2019/880 and its implementation will need to be reviewed in order to reach its goals. Regulation (EU) 2019/880 seeks to protect cultural heritage and prevent money laundering and terrorism financing by regulating the import of cultural goods into one of the largest art markets in the world. The Regulation however suffers from several shortcomings with respect to various issues. The article analyses four of these issues, starting with the process of creation of Regulation (EU) 2019/880 and the main critique of it being based on (too) little evidence. Moreover, attention is paid to the necessary practicalities of the European-wide implementation of Regulation (EU) 2019/880, the complexity caused by the use of the 1970 UNESCO Convention definitions to define cultural goods, as well as the practical ramifications of the use of the concept "country of creation or discovery". Drawing on these findings the article questions whether this Regulation in its current form is likely to have its intended effects.
\end{abstract}

\footnotetext{
* Anna M. de Jong is a PhD candidate in the Department of International \& European Law at the Faculty of Law of Maastricht University (the Netherlands). She holds an LLB in Dutch Law from Utrecht University (the Netherlands), an LLM in International Law with a specialization in Corporate and Commercial Law from Maastricht University, and an LLM from Duke University (United States of America). Her research primarily concerns regulation of the trade in cultural goods, with a particular focus on the European legal framework against money laundering, terrorism financing, and looting and destruction of cultural heritage. Before joining the Maastricht Law Faculty, she gained practical experience at several law firms.
} 


\section{GENERAL ARTICLES}

Anna M. de Jong

Keywords: cultural goods, import control mechanism, Regulation (EU) 2019/880, money laundering, terrorism financing

\section{Introduction}

Judging it purely by its objectives, the enactment of Regulation (EU) 2019/880 of the European Parliament and of the Council of 17 April 2019 on the introduction and the import of cultural goods ("Regulation (EU) 2019/880" or "Regulation") ${ }^{1}$ should have been met with resounding applause. Not only does it seek to protect cultural goods from being stolen, destroyed, or illicitly traded, it also aims to prevent terrorism financing and money laundering through the European art market. The Regulation was also far from unexpected. Other (inter)national actors had also highlighted the current risks being faced by cultural heritage, and the unwanted and illegal goals potentially achieved through the (illicit) circulation of cultural goods. Action was consequently taken on both the national and international levels. By way of example, the UN Security Council alone adopted five different resolutions ${ }^{2}$ in response to the damaging, looting, and destruction of cultural heritage by the terrorist group ISIL. ${ }^{3}$

Moreover, Regulation (EU) 2019/880 is only the most recent addition to the rules applicable in the European Union (EU) regulating the circulation of cultural goods. ${ }^{4}$

\footnotetext{
1 OJ L 151, 7.06.2019, p. 1.
}

2 UN Security Council Resolution 2195, 19 December 2014, S/RES/2195 (2014); UN Security Council Resolution 2199, 12 February 2015, S/RES/2199 (2015); UN Security Council Resolution 2249, 20 November 2015, S/RES/2249 (2015); UN Security Council Resolution 2253, 17 December 2015, S/RES/2253 (2015); UN Security Council Resolution 2347, 24 March 2017, S/RES/2347 (2017). For more on the significantly increased role and activity of the UN Security Council in the area of counterterrorism in the last two decades, see D. McKeever, Revisiting Security Council Action on Terrorism: New Threats; (a Lot of) New Law; Same Old Problems?, "Leiden Journal of International Law" 2021, Vol. 34(2), pp. 1-30. For a broader overview of the measures taken by various (inter)national actors see, e.g., P.L. Mahnad, Protecting Cultural Property in Syria: New Opportunities for States to Enhance Compliance with International Law?, "International Review of the Red Cross" 2017, Vol. 99(3), pp. 1037-1074.

3 The Islamic State of Iraq and the Levant, also known as ISIS, IS, or Daesh.

4 Not too long before Regulation (EU) 2019/880, the Fifth Anti-Money Laundering Directive (officially known as Directive (EU) 2018/843 of the European Parliament and of the Council of 30 May 2018 amending Directive (EU) 2015/849 on the prevention of the use of the financial system for the purposes of money laundering or terrorist financing, and amending Directives 2009/138/EC and 2013/36/EU, OJ L 156, 19.06.2018, p. 43) was adopted. Among other things, this Directive amended the current Anti-Money Laundering Framework of the European Union to also cover "persons trading or acting as intermediaries in the trade of works of art" as well as "persons storing, trading or acting as intermediaries in the trade of works of art when this is carried out by free ports" in cases where "the value of the transaction or a series of linked transactions amounts to EUR 10000 or more". Even though the Directive may thus have an indirect impact on the circulation of cultural goods, it does not directly regulate said circulation and is therefore mostly kept outside the scope of this article. 
The export and internal illicit circulation of cultural goods already fell within the scope of, respectively, Regulation (EC) 116/20095 and Directive 2014/60/EU. ${ }^{6}$ Only one part of the puzzle was thus still missing, namely the import of cultural goods. ${ }^{7}$ With the adoption of Regulation (EU) 2019/880 this lacuna has, at least on paper, been resolved.

Still, Regulation (EU) 2019/880 has entered the world surrounded by criticism from divergent sources. This has to do with not just the legal, but also the practical issues which are currently left unresolved. Due to these unresolved issues the Regulation severely risks being unable to fulfil its crucial mission of cultural heritage protection on the one hand, and the prevention of money laundering and terrorism financing on the other. In fact, as will be made clear in this article, some of these issues may actually increase the propensity of illicit practices involving cultural goods. This is especially alarming considering that in 2019 the total value of cultural goods imported into the EU was estimated at around $€ 18.5$ billion. ${ }^{8}$ The importance and potential impact of the Regulation therefore cannot be understated.

Four of the main issues concerning the Regulation will be analysed in this article. This will be done by first looking at the process of the creation of Regulation (EU) 2019/880 and the main critique of it as being based on (too) little evidence. Thereafter, consideration is given to the practicalities of the European implementation of Regulation (EU) 2019/880. As is made clear, without effective implementation the Regulation risks becoming no more than a paper tiger; impressive on paper but not nearly as daunting or effective in practice. Next, two main points of contention are singled out regarding the text of the Regulation. Particular attention is paid to its method of defining "cultural goods", as well as the centrality of the "country of creation or discovery" and consequent potential pitfalls. Through the analysis of these issues it will become clear where improvements are necessary, and the direction such improvements may take.

5 Council Regulation (EC) No 116/2009 of 18 December 2008 on the export of cultural goods, OJ L 39, 10.02.2009, p. 1.

6 Directive 2014/60/EU of the European Parliament and of the Council of 15 May 2014 on the return of cultural objects unlawfully removed from the territory of a Member State and amending Regulation (EU) No 1024/2012 (Recast), OJ L 159, 28.05.2014, p. 1.

7 It can be argued that there is a fourth dimension to the circulation of cultural goods which also is not yet regulated; namely the illicit internal circulation of cultural goods which are not deemed a "national treasure" as required in order to fall within the scope of Directive 2014/60, but still deserving of a special status due to either their cultural significance to (a people of) a non-Member State or the inherent scientific, artistic, or cultural value of the object in question. However, as has been convincingly discussed by, e.g., Anna Frankiewicz-Bodynek and Piotr Stec in a previous edition of this journal, even the current exception of only "national treasure" can already cause significant undue hindrance to the free circulation of goods. A. Frankiewicz-Bodynek, P. Stec, Defining "National Treasures" in the European Union. Is the Sky Really the Limit?, "Santander Art and Culture Law Review" 2019, Vol. 5(2), pp. 77-94.

8 The total value of cultural goods imported by EU Member States was estimated at around $€ 37.9$ billion, with $48.7 \%$ of the goods imported from non-member countries. Source: Eurostat, International trade in cultural goods, https://ec.europa.eu/eurostat/web/culture/data/database, 2020. 


\section{GENERAL ARTICLES}

Anna M. de Jong

\section{"Little Evidence" as the Basis of Regulation (EU) 2019/880}

The import of cultural goods had been regulated before by the EU in the form of ad hoc prohibitions. In 2003 the European Council adopted Council Regulation (EC) No. $1210 / 2003^{\circ}$ as a result of the war in Iraq and various related UN Security Council Resolutions. ${ }^{10}$ This Council Regulation prohibited trade in cultural objects when there was reasonable ground to believe these objects were illicit. ${ }^{11}$ In 2012 it adopted Council Regulation (EU) No. 36/2012, laying down a similar ad hoc prohibition of trade in cultural objects from Syria where there was reasonable ground to believe these objects were illicit. ${ }^{12}$ Neither of these measures however provided a satisfactory solution to the potential import of illicit cultural goods. In the words of the European Commission: "These trade restrictions depend on the continuation of the specific sanctions regimes and provide only a partial response and the burden of proof required for customs to establish the origin of such goods is high". ${ }^{13}$

Unsurprisingly, the EU started thinking about new measures in the following years. In 2015 the EU thus renewed its Internal Security Strategy, resulting in a new European Agenda on Security for the then-upcoming five years. ${ }^{14}$ One of the points listed in this Agenda is examination of the necessity and desirability of "additional measures in the area of terrorism financing". ${ }^{15}$ Included as possible areas covered by such measures are money laundering in general and the "illicit trade in cultural goods" specifically.

9 Council Regulation (EC) No 1210/2003 of 7 July 2003 concerning certain specific restrictions on economic and financial relations with Iraq and repealing Regulation (EC) No 2465/96, OJ L 169, 8.07.2003, p. 6.

10 The Regulation in particular mentions United Nations Security Council Resolution 661 (1990) and Resolution 986 (1995).

11 This Regulation was preceded by Council Regulation (EC) No 2465/96 of 17 December 1996 concerning the interruption of economic and financial relations between the European Community and Iraq, OJ L 337, 27.12.1996, p. 1. Regulation 2465/96 however involved a blanket ban on all goods (except those goods whitelisted by it for humanitarian purposes or relating to the Kirkuk-Yumurtalik pipeline), without any specific reference to cultural goods. In contrast, Regulation 1210/2003 explicitly lists "Iraqi cultural property and other items of archaeological, historical, cultural, rare scientific and religious importance" as falling within its scope (see Article 3). Regulation 1210/2003 has continuously been amended by various Regulations since its creation. Its most recent amendment at the time of this writing occurred on 6 July 2021 (Commission Implementing Regulation (EU) 2021/1111 of 6 July 2021 amending Council Regulation (EC) No 1210/2003 concerning certain specific restrictions on economic and financial relations with Iraq, OJ L 239, 7.07.2021, p. 22).

12 Council Regulation (EU) No 36/2012 of 18 January 2012 concerning restrictive measures in view of the situation in Syria and repealing Regulation (EU) No 442/2011, OJ L 16, 19.01.2012, p. 1.

13 European Commission, Communication from the Commission to the European Parliament and the Council on an Action Plan for strengthening the fight against terrorist financing, 2 February 2016, COM(2016) 50, p. 12.

14 European Commission, Communication from the Commission to the European Parliament, the Council, the European Economic and Social Committee and the Committee of the Regions: The European Agenda on Security, 30 April 2015, COM(2015) 185.

15 Ibidem, p. 14. 
The 2015 European Agenda on Security was closely followed by the 2016 "Action Plan to step up the fight against terrorism". ${ }^{16}$ This Action Plan provided further details on what the "additional measures in the area of terrorism financing" could entail. At the end of the second out of (only) two paragraphs discussing the risk of illicit excavations, the Commission noted it would consider "the introduction of a certification system for the import of cultural goods into the EU" ${ }^{17} \mathrm{~A}$ year later the Commission revealed the outcome of these considerations. It forwarded "a Proposal for a Regulation of the European Parliament and of the Council on the import of cultural goods" to the European Parliament for consideration. ${ }^{18}$

The timing and continued advancement of this proposal is peculiar. Less than a month before the release of the proposal the European Commission also released its report on the outcome of its first supra-national assessment of the risks of money laundering and terrorism financing activities, both within and crossing the Union's borders. Interestingly, the report stresses that "a clear understanding and analysis of ML and TF risks is a pre-requisite before any efficient and adequate policy response can be made". ${ }^{19}$ This quote becomes especially remarkable considering that in the Commission Staff Working Document accompanying the Report (providing a full overview of the Risk Assessment Report), it is stated that both in relation to money laundering and terrorism financing there is "little evidence" either would be occurring in the European art and antiquities market. ${ }^{20}$ In fact, only one source is explicitly mentioned in relation to the (perceived) connection between terrorism financing, money laundering, and the European art and antiquities market, namely a report by the International Centre for the Study of Radicalisation (ICSR) published in 2017. ${ }^{21}$ This very same ICSR report however explicitly warns the reader, among other things, that "[ $t$ ] he [research] results are necessarily imperfect, because they rely on a good deal of triangulation and many assumptions which may not, in all cases, stand the test of time". ${ }^{22}$

\footnotetext{
$16 \operatorname{COM}(2016) 50$.

17 Ibidem, p. 12.

18 European Commission, Proposal for a Regulation of the European Parliament and of the Council on the import of cultural goods, 13 July 2017, COM(2017) 375.
}

19 European Commission, Report from the Commission to the European Parliament and the Council on the assessment of the risks of money laundering and terrorist financing affecting the internal market and relating to cross-border activities, 26 June 2017, COM(2017) 340, p. 2.

20 European Commission, Commission Staff Working Document accompanying the document Report from the Commission to the European Parliament and to the Council on the assessment of the risks of money laundering and terrorist financing affecting the internal market and relating to cross-border situations, 26 June 2017, $\operatorname{SWD}(2017)$ 241, pp. 125, 126.

21 Ibidem, pp. 124-128.

22 S. Heißner et al., Caliphate in Decline: An Estimate of Islamic State's Financial Fortunes, The International Centre for the Study of Radicalisation and Political Violence (ICSR), London 2017, p. 6. 


\section{GENERAL ARTICLES}

Anna M. de Jong

Nevertheless the report as published by the European Commission still claims that: "The trafficking in cultural goods is among the biggest criminal trades, estimated to be the third or fourth largest, and despite the fact that there are hardly any instruments for measuring this trade or any data on illicit commerce". ${ }^{23}$ In particular the first half of this statement is often cited, despite the fact that, as indicated by the European Commission and others ${ }^{24}$ - and even in the second part of the quote itself - there simply isn't enough data to verify the validity of this bold claim. A communiqué published by the European Commission roughly half-a-year earlier explains part of this lack of data, while simultaneously pointing out one of the main challenges of preventing the circulation of illicit cultural objects, as follows:

While EU customs are uniquely well-placed at the stage of physical delivery to intercept incoming illicit cultural goods and prevent trafficking, they lack the appropriate legal and operational means, as well as sufficient access to specialised expertise, to carry out the difficult task of detecting and, most of all, proving the illicit character of the goods. ${ }^{25}$

A report which could have provided a better overview of the (potential) problem was commissioned in late 2017, to be published in the summer of 2019. ${ }^{26} \mathrm{How}$ ever, the Regulation was adopted before the final publication of the report. ${ }^{27}$ It is thus unlikely that the Regulation and (the perception of) the problems it seeks to combat are based on hard data. This is especially problematic considering the report also noted that the continued existence of open questions would prevent effective responses to the issues the Regulation seeks to tackle. ${ }^{28}$

\footnotetext{
23 SWD(2017) 241, p. 124.

24 For example, see M. Durney, Reevaluating Art Crime's Famous Figures, "International Journal of Cultural Property" 2013, Vol. 20(2), pp. 221-232.

25 European Commission, Inception Impact Assessment. Title of Initiative: Import of Cultural Goods, 2016.

26 Brodie and Yates Completing Study on Illicit Trafficking of Antiquities Through Europe for the European Commission, 10 July 2018, https://traffickingculture.org/news/brodie-and-yates-completing-study-on-illicit-trafficking-of-antiquities-through-europe-for-the-european-commission/ [accessed: 28.04.2021].

27 The final report was published 12 July 2019. The Regulation was adopted on 17 April 2019. For the full final report see N. Brodie et al., Illicit Trade in Cultural Goods in Europe. Characteristics, Criminal Justice Responses and an Analysis of the Applicability of Technologies in the Combat Against the Trade, Publications Office of the European Union, Luxembourg 2019. As confirmed by Dr. Yates, co-author of the report, interim reports and presentations submitted to the Commission in advance of its publication did not provide as much information as the final report.
}

28 Ibidem, pp. 199-200, 204-208. 


\section{Potential Problems with the Implementation of the Regulation}

The previously-mentioned quote from the European Commission communiqué (footnote 25) already highlighted the necessity to pay sufficient attention to the practical implementation of the Regulation. It made clear that without the needed tools being provided to customs and other relevant enforcement agencies, the Regulation would risk ending up being no more than a paper tiger; effective on paper, but in practice lacking the means to actually be a force to be reckoned with. The final text of the Regulation demonstrates an awareness of this potential pitfall. Already in the third paragraph of the preamble it is stated that in relation to cultural goods "ineffective enforcement [...] lead to the transfer of such goods to the shadow economy". ${ }^{29}$ Thus the central role and needs of customs authorities is stressed. ${ }^{30}$

The Risk Assessment Report on money laundering and terrorism financing affecting the internal market, as published in 2019 by the Commission, however already gave cause for concern. Not only did "customs authorities [still] have difficulties detecting the illicit origin of cultural artefacts", but law enforcement agencies are referred to as stating "cultural artefacts either do not arrive on EU territory or remain undetected". ${ }^{11}$ In other words, customs and enforcement authorities at the very least did not have the means to effectively impose Regulation (EU) 2019/880 when it was first created.

The Regulation does mention several options to potentially aid the work of customs agencies. These range from the ability to request further information from the declarant, physical examination of the goods, ${ }^{32}$ the use of the UNESCO-recommended Object ID standard, ${ }^{33}$ to increased cooperation in relation to training, capacity building, and data sharing, ${ }^{34}$ with the use of an electronic system at its core. ${ }^{35}$ Most of these measures are however dependent on further acts by the European Commission, in particular the use of the electronic system. To complicate matters, the initial proposal of the Regulation did not include the obligation upon the Commission to create this centralized electronic system.

\footnotetext{
29 Regulation (EU) 2019/880, preamble, para. 3.

30 Ibidem, preamble, para. 14.

31 European Commission, Commission Staff Working Document accompanying the document Report from the Commission to the European Parliament and to the Council on the assessment of the risk of money laundering and terrorist financing affecting the internal market and relating to cross-border activities, 24 June 2019, SWD(2019) 650, p. 153.

32 Regulation (EU) 2019/880, preamble, para. 14.

33 Ibidem, preamble, para. 15.

34 Ibidem, preamble, para. 23.

35 Ibidem, preamble, paras. 16, 22 and Arts. 8, 9.
} 


\section{GENERAL ARTICLES}

Anna M. de Jong

Sufficient resources were therefore not available from the start. ${ }^{36}$ In practice this meant that instead of the necessary two staff members only one has been allocated to the project, and then not until late September 2019. ${ }^{37}$ Unsurprisingly, in 2020 the Commission therefore already had to report the implementation process as being behind schedule. ${ }^{38}$ The recent 2021 progress report painted a slightly more optimistic picture, but still also mentioned several risks of delays. Whereas the budget now seems to be secured under the 2021-2027 Multiannual Financial Framework, the lack of second staff member remains. ${ }^{39}$ Moreover, like the 2020 progress report, the 2021 progress report warns of the impact of the COVID-19 health crisis. As stated by the report, "the COVID-19 public health crisis is affecting to some extent the team's capacity to deliver and especially the project activities and meetings with the Expert Group and the Project Group with the Member States". 40

This is however not the only avenue through which COVID-19 may impact the implementation of the Regulation. Combined with the receding influence of ISIL, political attention to the need of cultural heritage protection and the combatting of illicit trade in artefacts has in particular waned. The crisis thus not only impacted the efficiency of those resources already allocated, it has also shifted the priorities of the Member States, which may well impact the quantity and quality of resources made available for the (effective) future implementation of the Regulation.

36 European Commission, Report from the Commission to the European Parliament and the Council pursuant to Article 14(3) of Regulation (EU) 2019/880 of the European Parliament and of the Council of 17 April 2019 on the introduction and the import of cultural goods, 30 July 2020, COM(2020) 342, pp. 7-8.

37 Whether this means a staff member has been working continuously on the project since September 2019 is unclear. The progress reports seem to indicate there has at least been a change of staff. Whereas the progress report of 2020 mentions that "only one contract staff could be allocated, from late September 2019", the 2021 report states "only one full time Administrator could be allocated from mid-July 2020". More importantly, the reports do not make clear whether the mentioned Administrator's start date directly followed the end date of the contract staff's contract, or whether there may also have been a potential gap where no staff was working on the project. See $\operatorname{COM}(2020) 342$, p. 7; in conjunction with European Commission, Report from the Commission to the European Parliament and the Council pursuant to Article 14(3) of Regulation (EU) 2019/880 of the European Parliament and of the Council of 8 July 2020 on the introduction and the import of cultural goods, 8 July 2021, COM(2021) 358, p. 8.

$38 \operatorname{COM}(2020) 342$, p. 8.

$39 \operatorname{COM}(2021) 358$, pp. 8-10.

40 As explained by the 2021 progress report, "[m]eetings were held in a virtual format, with shorter agendas and limited interaction", see ibidem, pp. 8-9. More detailed information on this point was given in the 2020 progress report. The Expert Group for example had to cancel at least one of its sessions in 2020 , with the Project Group having had to reduce its session time to only one third of its usual length, see $\operatorname{COM}(2020) 342$, p. 8. 


\section{The Obtrusiveness of the Definition Chosen for "Cultural Goods"}

A lack of data at its creation and potentially delayed or insufficient implementation are however only two of points of concern relating to the Regulation. Further criticism has been raised concerning the definition of "cultural goods" as promulgated by the Regulation.

In Article 2 of the Regulation "cultural goods" are defined as those of archaeological, prehistoric, historical, literary, artistic, or scientific importance as listed in one of the annexes to the Regulation. In annexes $A, B$, and $C$ we thus find further categorization and definitions of the cultural goods included. The categorization and definitions in these annexes are based on the now more than 50-year-old definitions laid down by the 1970 UNESCO Convention, ${ }^{41}$ as only slightly adjusted by the 1995 UNIDROIT Convention. ${ }^{42}$ Ostensibly this has been done for reasons of "familiarity". ${ }^{43}$ The choice to use the UNESCO definitions however creates several issues.

First of all, the use of the UNESCO definitions means there is a notable difference between what qualifies as "cultural goods" within, respectively, the contexts of import, export, and illicit internal circulation. The earlier-mentioned Regulation (EU) 116/2009 on the export of cultural goods also defines cultural goods by reference to a separate annex. Unlike the annexes of Regulation (EU) 2019/880, this annex however contains tailor-made definitions which, while clearly also inspired by the same 1970 UNESCO definitions, are materially different. Moreover, due to this divergence, a greater level of specificity is reached by Regulation (EU) 116/2009. By way of example, whereas Regulation 2019/880 groups together practically all pictures, paintings, and drawings, ${ }^{44}$ Regulation (EU) 116/2009 makes a distinction between, among other things, pictures and photographs, with pictures being even further divided into several categories, and with a different financial threshold for each category. ${ }^{45}$

\footnotetext{
41 UNESCO Convention on the Means of Prohibiting and Preventing the Illicit Import, Export and Transfer of Ownership of Cultural Property, 14 November 1970, 823 UNTS 231.

42 UNIDROIT Convention on Stolen or Illegally Exported Cultural Objects, 24 June 1995, 34 ILM 1322. Both Conventions define "cultural property" as "property which, on religious or secular grounds, is of importance for archaeology, prehistory, history, literature, art or science"; with the original UNESCO definition adding the necessity of the object or property in question being designated as such by a State. This requirement of State-based denomination has been dropped both by the UNIDROIT Convention as well as Regulation (EU) 2019/880.
}

43 Regulation (EU) 2019/880, preamble, para. 7.

44 Ibidem, Annex A(g)(i) and Annex C(g)(i).

45 Regulation (EU) 116/2009, Annex I, A(3)(4)(5)(8), in combination with Annex I, B. 


\section{GENERAL ARTICLES}

Anna M. de Jong

Directive 2014/60/EU deals with the return of cultural objects unlawfully removed from the territory of a Member State. Within this context of illicit internal circulation of cultural goods, "cultural goods" are seen as those goods falling under the "national treasure" umbrella enshrined in Article 36 of the Treaty on the Functioning of the European Union (TFEU). ${ }^{46}$ Intriguingly, this is a departure from its predecessor (Council Directive 93/7/EEC ${ }^{47}$ ). Under the predecessor Directive, cultural goods not only had to meet the "classified national treasure" standard, but also had to fit into one of the categories listed in an attached annex as well as exceed a financial threshold of assessed value. ${ }^{48}$ Even more puzzling, the categorization in this now-defunct annex as well as the chosen financial thresholds are nearly identical to the ones currently in place for Regulation (EU) 116/2009.49

While the term "national treasure" as used in both Article 36 TFEU and Directive 2014/60/EU has been criticized as being ambiguous, with its meaning differentiating from one authentic language version to another, ${ }^{50}$ and being too focused around State action, ${ }^{51}$ it still is unclear why no use has been made in Regulation (EU) $2019 / 880$ of the same definitions as Regulation (EU) 116/2009. The choice to stick to the UNESCO definitions for Regulation (EU) $2019 / 880$ is thus already an unfortunate one from the viewpoint of cohesion between European instruments. With its use of the old UNESCO definitions, the Regulation adds yet another divergent definition of "cultural goods" among otherwise closely-related European legislation.

One more factor makes the choice to stick to the UNESCO definitions additionally questionable. UNESCO itself has recognized and underlined that while the 1970 UNESCO definitions may function well as a basis to work from, they do need adapting to fully fit contemporary goals and needs. In the Operational Guidelines as adopted by the UNESCO Member States in 2015, Member States are therefore

\footnotetext{
46 Directive 2014/60, Art. 2, para. 1.

47 Council Directive 93/7/EEC of 15 March 1993 on the return of cultural objects unlawfully removed from the territory of a Member State, OJ L 74, 27.03.1993, p. 74.

48 See also M. Frigo, The Implementation of Directive 2014/60/EU and the Problems of the Compliance of Italian Legislation with International and EU Law, "Santander Art and Culture Law Review" 2016, Vol. 2(2), p. 74. 49 Under Council Directive 93/7/EEC, "[w]atercolours, gouaches and pastels executed entirely by hand on any material" were not listed as a separate category.

50 As stated by, among others, Robert Peters, "whereas Article 36 TFEU in the English and French versions refers to 'national treasures' (French: trésors nationaux), the Italian and Spanish versions of Article 36 TFEU refer to 'patrimonio nazionale' (Spanish: patrimonio nacional). The latter suggests a much broader understanding of 'national heritage' or 'national patrimony' than the term 'national treasures', which indicates that the provisions might be limited to a few precious items". R. Peters, The Protection of Cultural Property: Recent Developments in Germany in the Context of New EU Law and the 1970 UNESCO Convention, "Santander Art and Culture Law Review" 2016, Vol. 2(2), p. 89. See also H.E.G.S. Schneider in: A. Bleckmann, Europarecht. Das Recht der Europäischen Gemeinschaft, Carl Heymanns Verlag, Cologne 1990, pp. 804-808.
}

51 See also footnote 7. 
specifically encouraged to update these definitions of cultural property. ${ }^{52}$ Nonetheless, we find near-exact copies of the UNESCO definitions in the annexes of Regulation (EU) 2019/880. Only two differences can be noted. Instead of "property of artistic interest" 53 there is now the category "objects of artistic interest" ${ }^{54}$ In addition, "rare manuscripts and incunabula" have been removed from their overarching category and separated into their own. ${ }^{55}$

Second, due to the lack of specificity of the 1970 UNESCO definitions, the precise categorization of objects has become a complicated puzzle. Objects may well risk either falling between categories, or falling into several categories at once. This is especially problematic since the specific categorization of a given cultural good is critical under Regulation (EU) 2019/880. An importer of goods falling under one of the categories governed by Article 4 needs to apply for an importer license, whereas goods falling under Article 5 merely need an importer statement. An importer license requires the importing party to provide evidence the goods have been licitly exported out of the country of origin of the goods. ${ }^{56}$ In contrast, an importer statement merely requires the importing party to declare the goods licitly exported, without the strict necessity of providing further evidence. ${ }^{57}$ This stark difference encourages shenanigans. Who can say with certainty an object is only 249 years old, instead of $250+$, and therefore excluded from the strict regime of Article 4? Or worth no more than $€ 17,999$, instead of $€ 18,000+$, and therefore (also) excluded from Article 5?

Third, and perhaps most crucially, the use of the 1970 UNESCO definitions in combination with the added thresholds leads to some of the objects which are most in need of protection falling outside the scope of the Regulation. Ancient coins and jewellery are seen as among the most likely kind of cultural objects being trafficked

52 UNESCO, Operational Guidelines for the Implementation of the 1970 Convention as Adopted during the Third Meeting of States Parties to the 1970 Convention on the Means of Prohibiting and Preventing the Illicit Import, Export and Transfer of Ownership of Cultural Property, UNESCO, Paris 2015.

531970 UNESCO Convention, Art. 1, para.g.1.

54 Regulation 2019/880, Annex A(g) and Annex C(g).

55 Compare 1970 UNESCO Convention, Art. 1, para. h, with Regulation 2019/880, Annex A(h) and (i), and Annex C(h) and (i).

56 In case it is not possible to determine the country of creation or discovery or if the goods were exported out of the country of origin before 1972, the legitimacy of the export out of the country the goods have last been in for more than 5 years has to be proven instead (Regulation 2019/880, Art. 4, paras. 1 and 4).

57 Here too the export concerns the export from the country of creation or discovery or, when impossible to determine or transported out of the country of origin before 1972, export from the country where the goods have last been in for more than 5 years (Regulation (EU) 2019/880, Art. 5, paras. 1 and 2). While the Commission may, through implementing acts, require the importing party to at least possess certain documents to act as supporting evidence (Art. 5, para. 3), there currently is no indication of the adoption of such implementing acts happening anytime soon. Moreover, mere possession instead of forced submission of supporting documents to gain permission to import still constitutes a (significantly) lower bar than the one enshrined in Article 4. 


\section{GENERAL ARTICLES}

Anna M. de Jong

out of conflict zones. ${ }^{58}$ Even so, as noted by Neil Brodie, ancient coins will in the majority of cases fall outside the scope of the Regulation. ${ }^{59}$ Archaeological finds are covered by Article 4, yet Article 5 regulates "antiquities more than 100 years old, such as coins..." but only when they are worth over $€ 18,000.60$ Ancient coins thus seemingly do not fall under the category of archaeological finds of Article 4, nor will most coins meet the financial threshold necessary to fall under Article 5.

\section{The Complexity of the Key Concept "Country of Creation or Discovery"}

The text of the Regulation contains further points of attention. Articles 3, 4, and 5 , which form the main body of the Regulation, all revolve around the concept of the "country of creation or discovery". ${ }^{61}$ In practice this is difficult to determine for many cultural objects. ${ }^{62}$ The older the emergence of the object, the less likely it is that it is (still) known exactly where the object was first created or discovered. While living memory may still be able to help with localization of an object created or found in the last few decades, this will not be so for an object created or found in the first half of the 20th century or earlier. Furthermore, previous recordings of provenance may well not be up to our contemporary standards. In addition, documents or other evidence which could have provided a clue to an object's origin may well be lost to the passage of time. Moreover, export control regimes differed (and continue to differ) between countries..$^{63} \mathrm{~A}$ few countries already had some form of export controls in place since the late 19th century, but this certainly wasn't the case for all. ${ }^{64}$ An export license may thus not always be there, even when the export was neither illicit nor illegal.

58 See, among others, W.A. Terrill, Antiquities Destruction and Illicit Sales as Sources of ISIS Funding and Propaganda, Strategic Studies Institute, US Army War College, Carlisle 2017; S. Pineda, Tackling Illicit Trafficking of Antiquities and its Ties to Terrorist Financing, U.S. Department of State, 20 June 2018, https://2017-2021. state.gov/tackling-illicit-trafficking-of-antiquities-and-its-ties-to-terrorist-financing/index.html [accessed: 02.05.2021].

59 N. Brodie, Heart of Confusion? EU Regulation 2019/880 on the Import of Cultural Goods and the Fight Against Terrorism, 17 January 2020, https://marketmassdestruction.com/heart-of-confusion-eu-regulation-2019880-on-the-import-of-cultural-goods-and-the-fight-against-terrorism/ [accessed: 24.04.2021].

60 Regulation (EU) 2019/880, Annex B(c) and Annex C(e).

61 Ibidem, Art. 3, para. 1, and Art. 4, para. 1. See also point 8 of the preamble.

62 Recall also the difficulty mentioned by the European Commission for customs agencies to prove objects came from Iraq or Syria under the ad hoc trade restrictions. See footnote 11.

63 J.A.R. Nafziger, Trading and Returning Cultural Objects under International Law, "Santander Art and Culture Law Review" 2016, Vol. 2(2), p. 191.

64 R.K. Paterson, J.A.R. Nafziger, Report on National Controls over the Export of Cultural Material, Report of the Seventy-fourth Conference of the International Law Association, 2010, p. 232; see also L.V. Prott, International Control of Illicit Movement on the Cultural Heritage: The 1970 UNESCO Convention and Some Possible Alternatives, "Syracuse Journal of International Law and Commerce" 1983, Vol. 10(2), pp. 334-337. 
Knowing the exact geographical location where an object was created or found still does not necessarily lead to instant clarity. Countries and borders of countries have been rather fluid in the past. The territory of current source countries has at times been redrawn. Even nowadays one can argue about under which country and consequent legal system the "Palestine territories" or the island of Taiwan fall. An assessment of the validity of an export by the standards of the "country of creation or discovery" in those cases thus requires making a profoundly political choice. On top of that, objects may well have travelled considerably during their process of creation. What exactly is the country of origin when dealing with a 15th century manuscript which has been printed in Italy, bound in France, illuminated in Belgium, and consequently sold in England? 65

All these potential factors combined make the determination of the exact "country of creation or discovery" a daunting task. While at first glance this may be seen as merely a pesky burden for the art dealer, or even desirable to stop the transit of "risky" goods, the problem is much more profound. First of all, Regulation (EU) 2019/880 does not just apply to professional art dealers. In principle any party wishing to import some kind of cultural object - from the enthusiastic individual wishing to explore a new hobby, to the professional aiming to further study a specific object, or an institute desiring to complement its permanent collection to showcase a piece of cultural, historic, scientific, or aesthetic significance - is affected by this "country of discovery of creation" conundrum. ${ }^{66}$

Moreover, the complexity of this core concept may well end up having a chilling effect on the legitimate trade in cultural objects as well. Examining the exact location of creation or discovery can be both time-consuming and cost-inducing. Those who do wish to adhere to the rules and remain in the legitimate market may simply not be able to do so.

Most pressingly, both the clarity of a given rule and the costs of complying with the rule are determinative of whether the rule will be abided by ${ }^{67}$ The higher the

65 This example is taken from Sibylle Wieduwilt, as cited in E. Polycarpou, D. Wierbicki, A.A. Rottermund, Tick Tock: Regulations on the Import of Non-EU-cultural Goods Are Now in Effect. How Will This Affect the International Art Market?, 27 June 2019, https://www.withersworldwide.com/en-gb/insight/tick-tock-regulations-on-the-import-of-non-eu-cultural-goods-are-now-in-effect-how-will-this-affect-the-internationalart-market [accessed: 2.05.2021].

66 The Regulation does have a few exceptions. All of these are however fairly restrictive. They are dependent on specific circumstances and limited to a few parties. Academic institutions, museums, or similar institutions are exempted in case of temporary admission of the cultural goods for one of the listed purposes in point 19 of the preamble. A license or statement when temporarily storing cultural goods exclusively for their safe keeping is not needed when done by or supervised by a public authority (point 20 of the preamble). Commercial art fairs may also opt for an import statement (instead of a license) unless the goods remain in the EU after the fair (point 21 of the preamble).

67 An abundance of sociological studies has been done into why actors may or may not comply with certain regulation. A detailed overview would go beyond the scope of this article. Nonetheless, see among others, C. Parker, V. Lehmann Nielsen (eds.), Explaining Compliance: Business Responses to Regulation, Edward Elgar Publishing, Cheltenham 2012; L. Harris, M. Gore, M. Mills, Compliance with Ivory Trade Regula- 


\section{GENERAL ARTICLES}

Anna M. de Jong

costs of compliance and the greater the complexity of the rule, the less likely an individual is to adhere to it. When the rules become too complex and/or costly, avoidance, instead of adherence, becomes the main goal. ${ }^{68}$ Given the above described complexity and impracticality of the concept of "country of creation or discovery", and in spite of its objectives of increased transparency and greater protection of cultural heritage, the Regulation risks inducing further secrecy and illicit trafficking instead.

The Regulation does allow for a possible way out of this "country of creation or discovery" conundrum. ${ }^{69}$ When the country of origin cannot be established, one may revert to the country the goods were last in for a period for more than 5 years. This stay must not have been for the purpose of temporary use, transit, re-export, or trans-shipment. ${ }^{70}$ This alternative has its benefits. Documents proving a presumably more recent long-term stay are more likely to (still) be there than documents or other evidence relating to the very first time an object was taken out of its country of creation or discovery. Nonetheless, this alternative also relies on documentation being both available as well as precise enough to identify the exact object in question. Moreover, it opens the door to less-than-scrupulous parties claiming the origin of the goods cannot be determined, and instead only providing evidence of a recent long-term stay. As a result, important information about provenance may become further obfuscated..$^{71}$

Even when it is possible to determine exactly from where an object originates, the hopeful importer still has several challenges to meet. Articles 4 and 5 also require the importing party to be familiar with the legal system of the country of creation or discovery at the time the object was initially taken out of said country. This creates two hurdles. First off, the hopeful importer will have to determine when exactly the object first crossed borders. Just like determining where an object first emerged, establishing when an object was first moved is often difficult. ${ }^{72}$

tions in the United Kingdom Among Traders, "Conservation Biology" 2019, Vol. 33(4), pp. 906-916; H. Elffers, P. van der Heijden, M. Hezemans, Explaining Regulatory Non-compliance: A Survey Study of Rule Transgression for Two Dutch Instrumental Laws, Applying the Randomized Response Method, "Journal of Quantitative Criminology" 2003, Vol. 19(4), pp. 409-439; P.J. May, Compliance Motivations: Affirmative and Negative Bases, "Law \& Society Review" 2004, Vol. 38(1), pp. 41-68.

68 In this light see also P. Bator, The International Trade in Art, University of Chicago Press, Chicago 1983, pp. 41-43, where it is argued that any overly legal approach to trade control will in effect only encourage increased illicit trade.

69 Regulation (EU) 2019/880, Art. 4, para. 4(a), and Art. 5, para. 2(a).

70 Ibidem, Art. 4, para. 4, and Art. 5, para. 2.

71 See also P. Valentin, F. Rogers, Adoption of the Regulation on the Import of Cultural Goods: Start Preparing Now!, Art@Law, 13 June 2019, https://www.artatlaw.com/adoption-of-the-regulation-on-the-import-ofcultural-goods-start-preparing-now/ [accessed: 3.05.2021]. 
This difficulty also impacts the other scenario in which the country of creation or discovery is replaced by the country of the last long-term stay. When the goods were removed from the country of creation or discovery before 24 April 1972, the hopeful importer can again revert to the country of last long-term stay. ${ }^{73}$ Here too this stay must not have been for the purpose of temporary use, transit, re-export, or trans-shipment. As has been stated, in practice however it can be difficult to establish when exactly an object was moved. More worryingly, this exception may lead to a rise in the use of "Exported prior to 1972" next to "Private Collection 1970". ${ }^{44}$

Moreover, assuming the hopeful importer manages to establish when exactly the object was first moved from its country of origin, he or she will have to establish which rules, if any, applied at that time. This means not only seeking out the correct legal system, but also determining the version of said system applicable at that time, and the correct interpretation of the rules of said version. Given the scope of the Regulation, this legal system will often be considerably alien. Cultural goods which were either created or discovered in the customs territory of the EU do not fall under Regulation (EU) 2019/880.75 In other words, the Regulation only deals with objects whose valid export will have to be established by reference to a non-European legal system. While European legal systems can already be quite dissimilar, generally the dissimilarity between a European legal system and a non-European legal system will be even greater. Problems of determination, interpretation, language, and inaccessibility and unfamiliarity with the (then-applicable) legal system of origin lie in wait just around the corner.

Again, this is more than just a theoretical issue. As stated before, compliance decreases when the difficulty and costs of compliance increase. With compliance less likely, checks and controls become essential. Yet the Regulation as it stands forces all actors involved to both correctly identify and comprehend legal systems which in the majority of cases will be completely alien to them. This is often difficult enough for trained lawyers, let alone for those without a strictly legal background, and this is true not only with respect to the hopeful importer but also for customs and other relevant enforcement agencies. The concept of the "country of creation or discovery" thus not only induces avoidance instead of compliance, its complicated nature risks a diminishing of the legitimate art and antiquities market and adds another hurdle to the actual enforcement of the Regulation as a whole.

\footnotetext{
73 Regulation (EU) 2019/880, Art. 4, para. 4(b), and Art. 5, para. 2(b).

74 P. Valentin, F. Rogers, op. cit.

75 Regulation (EU) 2019/880, Art. 1, para. 2.
} 


\section{GENERAL ARTICLES}

Anna M. de Jong

\section{Conclusions}

Regulation (EU) 2019/880 is to be lauded for the objectives it seeks to achieve. Several (potential) shortcomings will however have to be addressed to ensure it will achieve its goals. First of all, more research into the underlying issues is necessary. As mentioned by the Commission itself, an adequate policy response requires an adequate overview of the issue first. However, as has been made clear, relevant information was missing at the time of adoption of the Regulation. Even though more information has been gathered since then, given the (potential) impact and lofty objectives of the Regulation a fuller and deeper understanding is indispensable.

Moreover, the effectiveness of the Regulation is highly dependent upon customs and enforcement agencies. This not only requires the above-mentioned further data, but also a conscious choice to ensure that the relevant customs and enforcement agencies have the (technical) means, staffing, and expertise available to put the system into practice. It is unclear whether these agencies are capable (yet) of doing so.

In addition, the choice of the 1970 UNESCO definitions to define "cultural goods" is an unfortunate one. As related above, this choice has resulted in cultural goods being defined completely dissimilarly across otherwise closely-related European legislation. Even when focusing only on Regulation (EU) 2019/880 issues still remain. The combination of the 1970 UNESCO definitions in conjunction with certain age and financial thresholds result in cultural objects potentially falling into either several of the definitions at once, or none of the definitions at all. Alarmingly, among the kind of cultural goods most likely to fall outside any of the definitions, and consequently the scope of Regulation (EU) 2019/880, are some of the very kinds of cultural goods likely to fall victim to looting. While the 1970 UNESCO definitions may thus have the benefit of familiarity, their use in Regulation (EU) 2019/880 may inadvertently hinder full achievement of its objectives.

Furthermore, the concept of "country of creation or discovery" and its central position at the heart of the Regulation comes with its own set of intricacies. In practice it is difficult to establish where exactly an object was created or discovered, for a variety of reasons. Even when the exact geographical location is known, determination of which legal system applies may still be thorny. The Regulation offers a potential alternative when the country of creation or discovery cannot be reliably determined, or when the goods were removed from this country before 24 April 1972. Both of these categories are however still dependent on sufficient documents being available and come with the risk of further obfuscation of provenance by parties with sordid motives. Even when it is possible to determine where exactly an object comes from and which foreign legal system thus applies, there still is the issue of the correct identification and interpretation of foreign rules, adding complexity for both hopeful importers and customs and enforcement agencies. 
The potential unwanted consequences of these issues are numerous: avoidance instead of compliance; a decrease in the scope of the legitimate market combined with an increase of the illicit market, with at-risk cultural goods falling outside the legal scope; new loopholes to be exploited by unscrupulous parties; less legal coherence of the current European framework for the circulation of cultural heritage; and extra challenges hindering the work and goals of customs and other relevant agencies. In conclusion, while in spirit the Regulation is to be applauded, in practice it will need revisiting and additional measures in order to attain its goals of cultural heritage protection and the prevention of money laundering and terrorism financing.

\section{References}

Bator P., The International Trade in Art, University of Chicago Press, Chicago 1983.

Bleckmann A., Europarecht. Das Recht der Europäischen Gemeinschaft, Carl Heymanns Verlag, Cologne 1990.

Brodie and Yates Completing Study on Illicit Trafficking of Antiquities Through Europe for the European Commission, 10 July 2018, https://traffickingculture.org/news/brodie-and-yates-completing-study-on-illicit-trafficking-of-antiquities-through-europe-for-the-european-commission/ [accessed: 28.04.2021].

Brodie N., Heart of Confusion? EU Regulation 2019/880 on the Import of Cultural Goods and the Fight Against Terrorism, 17 January 2020, https://marketmassdestruction.com/ heart-of-confusion-eu-regulation-2019-880-on-the-import-of-cultural-goods-andthe-fight-against-terrorism/ [accessed: 24.04.2021].

Brodie N. et al., Illicit Trade in Cultural Goods in Europe. Characteristics, Criminal Justice Responses and an Analysis of the Applicability of Technologies in the Combat Against the Trade, Publications Office of the European Union, Luxembourg 2019.

Durney M., Reevaluating Art Crime's Famous Figures, "International Journal of Cultural Property" 2013, Vol. 20(2).

Elffers H., van der Heijden P., Hezemans M., Explaining Regulatory Non-compliance: A Survey Study of Rule Transgression for Two Dutch Instrumental Laws, Applying the Randomized Response Method, "Journal of Quantitative Criminology" 2003, Vol. 19(4).

European Commission, Commission Staff Working Document accompanying the document Report from the Commission to the European Parliament and to the Council on the assessment of the risks of money laundering and terrorist financing affecting the internal market and relating to cross-border situations, 26 June 2017, SWD(2017) 241.

European Commission, Commission Staff Working Document accompanying the document Report from the Commission to the European Parliament and to the Council on the assessment of the risk of money laundering and terrorist financing affecting the internal market and relating to cross-border activities, 24 June 2019, SWD(2019) 650.

European Commission, Communication from the Commission to the European Parliament, the Council, the European Economic and Social Committee and the Committee of the Regions: The European Agenda on Security, 30 April 2015, COM(2015) 185.

European Commission, Communication from the Commission to the European Parliament and the Council on an Action Plan for strengthening the fight against terrorist financing, 2 February 2016, COM(2016) 50. 


\section{GENERAL ARTICLES}

Anna M. de Jong

European Commission, Inception Impact Assessment. Title of Initiative: Import of Cultural Goods, 2016.

European Commission, Proposal for a Regulation of the European Parliament and of the Council on the import of cultural goods, 13 July 2017, COM(2017) 375.

European Commission, Report from the Commission to the European Parliament and the Council on the assessment of the risks of money laundering and terrorist financing affecting the internal market and relating to cross-border activities, 26 June 2017, COM(2017) 340.

European Commission, Report from the Commission to the European Parliament and the Council pursuant to Article 14(3) of Regulation (EU) 2019/880 of the European Parliament and of the Council of 17 April 2019 on the introduction and the import of cultural goods, 30 July 2020, $\operatorname{COM}(2020) 342$.

European Commission, Report from the Commission to the European Parliament and the Council pursuant to Article 14(3) of Regulation (EU) 2019/880 of the European Parliament and of the Council of 8 July 2020 on the introduction and the import of cultural goods, 8 July 2021, $\operatorname{COM}(2021) 358$.

Frankiewicz-Bodynek A., Stec P., Defining "National Treasures" in the European Union. Is the Sky Really the Limit?, "Santander Art and Culture Law Review" 2019, Vol. 5(2).

Frigo M., The Implementation of Directive 2014/60/EU and the Problems of the Compliance of Italian Legislation with International and EU Law, "Santander Art and Culture Law Review" 2016, Vol. 2(2).

Harris L., Gore M., Mills M., Compliance with Ivory Trade Regulations in the United Kingdom Among Traders, "Conservation Biology" 2019, Vol. 33(4).

Heißner S. et al., Caliphate in Decline: An Estimate of Islamic State's Financial Fortunes, The International Centre for the Study of Radicalisation and Political Violence (ICSR), London 2017.

Mackenzie S. et al., Trafficking Culture; New Directions in Researching the Global Market in Illicit Antiquities, Routledge, Abingdon 2020.

Mahnad P.L., Protecting Cultural Property in Syria: New Opportunities for States to Enhance Compliance with International Law?, "International Review of the Red Cross" 2017, Vol. 99(3).

May P.J., Compliance Motivations: Affirmative and Negative Bases, "Law \& Society Review" 2004, Vol. 38(1).

McKeever D., Revisiting Security Council Action on Terrorism: New Threats; (a Lot of) New Law; Same Old Problems?, "Leiden Journal of International Law" 2021, Vol. 34(2).

Nafziger J.A.R., Trading and Returning Cultural Objects under International Law, "Santander Art and Culture Law Review" 2016, Vol. 2(2).

Parker C., Lehmann Nielsen V. (eds.), Explaining Compliance: Business Responses to Regulation, Edward Elgar Publishing, Cheltenham 2012.

Paterson R.K., Nafziger J.A.R., Report on National Controls over the Export of Cultural Material, Report of the Seventy-fourth Conference of the International Law Association, 2010.

Peters R., The Protection of Cultural Property: Recent Developments in Germany in the Context of New EU Law and the 1970 UNESCO Convention, "Santander Art and Culture Law Review" 2016, Vol. 2(2).

Pineda S., Tackling Illicit Trafficking of Antiquities and its Ties to Terrorist Financing, U.S. Department of State, 20 June 2018, https://2017-2021.state.gov/tackling-illicit-traf- 
ficking-of-antiquities-and-its-ties-to-terrorist-financing/index.html [accessed: 02.05.2021].

Polycarpou E., Wierbicki D., Rottermund A.A., Tick Tock: Regulations on the Import of Non-EU-cultural Goods Are Now in Effect. How Will This Affect the International Art Market?, 27 June 2019, https://www.withersworldwide.com/en-gb/insight/tick-tock-regulations-on-the-import-of-non-eu-cultural-goods-are-now-in-effect-how-will-this-affect-the-international-art-market [accessed: 2.05.2021].

Prott L.V., International Control of Illicit Movement on the Cultural Heritage: The 1970 UNESCO Convention and Some Possible Alternatives, "Syracuse Journal of International Law and Commerce" 1983, Vol. 10(2).

Terrill W.A., Antiquities Destruction and Illicit Sales as Sources of ISIS Funding and Propaganda, Strategic Studies Institute, US Army War College, Carlisle 2017.

UNESCO, Operational Guidelines for the Implementation of the 1970 Convention as Adopted during the Third Meeting of States Parties to the 1970 Convention on the Means of Prohibiting and Preventing the Illicit Import, Export and Transfer of Ownership of Cultural Property, UNESCO, Paris 2015.

Valentin P., Rogers F., Adoption of the Regulation on the Import of Cultural Goods: Start Preparing Now!, Art@Law, 13 June 2019, https://www.artatlaw.com/adoption-of-the-regulation-on-the-import-of-cultural-goods-start-preparing-now/ [accessed: 3.05.2021].

\section{Overview of relevant legal instruments}

Commission Implementing Regulation (EU) 2021/1111 of 6 July 2021 amending Council Regulation (EC) No 1210/2003 concerning certain specific restrictions on economic and financial relations with Iraq, OJ L 239, 7.07.2021, p. 22.

Council Directive 93/7/EEC of 15 March 1993 on the return of cultural objects unlawfully removed from the territory of a Member State, OJ L 74, 27.03.1993, p. 74.

Council Regulation (EC) No 116/2009 of 18 December 2008 on the export of cultural goods, OJ L 39, 10.02.2009, p. 1.

Council Regulation (EC) No 1210/2003 of 7 July 2003 concerning certain specific restrictions on economic and financial relations with Iraq and repealing Regulation (EC) No 2465/96, OJ L 169, 8.07.2003, p. 6.

Council Regulation (EC) No 2465/96 of 17 December 1996 concerning the interruption of economic and financial relations between the European Community and Iraq, OJ L 337, 27.12.1996, p. 1.

Council Regulation (EU) No 36/2012 of 18 January 2012 concerning restrictive measures in view of the situation in Syria and repealing Regulation (EU) No 442/2011, OJ L 16, 19.01.2012, p. 1.

Directive (EU) 2018/843 of the European Parliament and of the Council of 30 May 2018 amending Directive (EU) 2015/849 on the prevention of the use of the financial system for the purposes of money laundering or terrorist financing, and amending Directives 2009/138/EC and 2013/36/EU, OJ L 156, 19.06.2018, p. 43.

Directive 2014/60/EU of the European Parliament and of the Council of 15 May 2014 on the return of cultural objects unlawfully removed from the territory of a Member State and amending Regulation (EU) No 1024/2012 (Recast), OJ L 159, 28.05.2014, p. 1. 


\section{GENERAL ARTICLES}

Anna M. de Jong

Regulation (EU) 2019/880 of the European Parliament and of the Council of 17 April 2019 on the introduction and the import of cultural goods, OJ L 151, 7.06.2019, p. 1.

UN Security Council Resolution 2195, 19 December 2014, S/RES/2195 (2014).

UN Security Council Resolution 2199, 12 February 2015, S/RES/2199 (2015).

UN Security Council Resolution 2249, 20 November 2015, S/RES/2249 (2015).

UN Security Council Resolution 2253, 17 December 2015, S/RES/2253 (2015).

UN Security Council Resolution 2347, 24 March 2017, S/RES/2347 (2017).

UNESCO Convention on the Means of Prohibiting and Preventing the Illicit Import, Export and Transfer of Ownership of Cultural Property, 14 November 1970, 823 UNTS 231.

UNIDROIT Convention on Stolen or Illegally Exported Cultural Objects, 24 June 1995, 34 ILM 1322. 